\title{
Effects of Accounting Bases on Financial Reporting in Nigeria: The Case of Kaduna State
}

\author{
Jimoh Ihiovi Ojo ${ }^{1}$, Njijong Ajabwoa Marcelus ${ }^{2}$ \\ ${ }^{1}$ Department of Local Government and Development Studies, Faculty of Administration, Ahmadu Bello University, Zaria, Kaduna State, \\ Nigeria \\ ${ }^{2}$ Department of Banking and Finance, Faculty of Social and Management Science, University of Buea, Buea, South West Region, Cameroon
}

Email Address:

Ihiovi2032@yahoo.com (J. I. Ojo), ajabnji@yahoo.com (N. A. Marcelus)

\section{To cite this article:}

Jimoh Ihiovi Ojo, Njijong Ajabwoa Marcelus. Effects of Accounting Bases on Financial Reporting in Nigeria: The Case of Kaduna State. International Journal of Business and Economics Research. Special Issue: Microfinance and Local Development.

Vol. 10, No. 1, 2021, pp. 27-33. doi: 10.11648/j.ijber.20211001.14

Received: April 28, 2020; Accepted: December 5, 2020; Published: January 12, 2021

\begin{abstract}
Local Government financial reporting across the country has been largely driven by cash accounting basis and this has attracted a lot of criticism based on the quality of informational content of such report. Therefore, this study is carried out to assess the Local Government accounting basis on the financial reporting in Nigeria with particular emphasis on all the Local Government in Kaduna State. The study utilized descriptive research design using the entire 23 Local Governments in Kaduna State using their annual reports and accounts as a source of information. Also, the study utilized stata 12 to analyzed the formulated multiple regression model. The descriptive result reveals that there is wide variation in the financial reporting quality among the Local Governments under investigation across the state. This was supported by the large mean value of the size of the local government with a mean value of 16.824 suggesting that the Local Governments under investigation are of different sizes and probably their reporting quality will certainly differ. The regression summary reveals that the cumulative explanatory variables are statistically significant in explaining the effects of Local Government accounting basis on financial reporting. Similarly, the entire individual variable shows that they were all statistically significant having $\mathrm{p}$-val $<0.05$. This outcome suggests that the study failed to accept the null hypothesis. Therefore, the study recommends that the councils should ensure consistence in financial reporting in order to guarantee reliable and verifiable financial information as contained in the annual reports and accounts.
\end{abstract}

Keywords: Local Government, Financial Reporting Quality, Accounting, Revenue, Expenditure

\section{Introduction}

Accounting bases in Local Government focuses on the needs of providing specific financial information to Local Government at a particular point in time. However, the hull mark and Local Government distinctive problem is how to account for its items since they provide services free at the point of delivery, financed primarily by taxation and grants while, the ultimate responsibility is usually held by politicians endowed with finite and short time horizons to the next election. In the crucial but narrow sense of accounting as a control that ensures financial probity and guards against corruption, financial reporting in Local Governments has been as influential as in any other kind of organization. However, private sector accounting has, since the beginnings of the profession, become systematically associated with a much wider sense of accounting, the use of money to measure the performance of businesses. In a business, the value of services provided is given by the money the business collects from the sales it makes; because money is also used to measure the cost of services rendered, money provides a universal measure of performance in the public sector.

The cost of services provided by Local Government is also measured in terms of money, because governments have to buy in the same markets in which businesses buy. But the effect of financing governments by taxation is that the recipients of governmental services do not express their satisfaction in money terms. That universal measure of performance is not available. The traditional response to this problem has been to limit the role of accounting in 
government to matters of financial probity: the proper recording of transactions, the control of spending against the budget, and the minimization of spending. Matters relating to the quantity and quality of services provided were left to service professionals and politicians.

Accounting bases in the public sector has been largely driven by cash base accounting. Cash-based accounting account for when cash is paid and received. By its nature, cash base accounting ignores too many economic events; accrual accounting, necessarily in combination with cash accounting is, in practice, the fullest method available for recording, measuring, and communicating such economic events. Whether for internal management of a government or for external accountability, cash accounting is too parsimonious with the truth. The benefits of accrual accounting are not, of course, free. Providing more, highquality information involves increased processing expense; it also requires training to understand fully its benefits. Moreover, accrual accounting, while addressing the unacceptable ease with which cash flows can be manipulated, introduces significant reliability problems of its own, necessitating additional audit resources. Cash-based accounting is, by its nature, more reliable than accrual-based accounting, other things being equal, but is much less relevant. Any of this approach adopted has their pro and coins on the quality of financial report of Local Government. Hence, the intent of this study is to empirically assess Local Government accounting basis on financial reporting in Nigeria.

\section{Conceptual Review}

The primary purpose of a private sector organization is to make profit. As a result of this, the focus of accounting in private sector is to enable the business to determine the profit of the business over a given period. However, because public sector (Local Government) are not run for the purpose of profit making, many factors influence government accounting such as the role of government in the different fields like health, Agriculture, Personnel, Finance, and education and the methods set by government to achieve its set objectives, [1]. The focus of accounting in government is the determination of how much money was received and the sources of such receipts, how much money was spent and for what purposes and what remains after meeting the financial obligations. This then means that government accounting is more concerned with information gathering that will enable government to prepare Receipts and Payments accounts as it is the case with Clubs and Societies rather than the profit and loss account of a private sector business. This point is reinforced by the fact that the Accountant-General of the Federation is referred to as the "Chief Accounting Officer for the receipts and payments of the government of the federation. As a result of more interest in receipts and payments account, the government accounting practice that evolved over the years focused on cash receipts and disbursements on the basis of budgetary headings to reveal the balances available at a given time under various heads and sub-heads of votes, [2] (McCosh, Whiting. and Howell, 1981).

This therefore means that the basis of accounting in government is normally the cash basis (or modified cash) rather than the accrual basis of the private sector. Under the cash basis, the government revenue is recorded and accounted for when cash is received and expenditure is incurred when cash is paid irrespective of the accounting period in which the benefit is received or the service rendered. This therefore means that the amount incurred by the government to purchase official car will be treated the same way as salaries paid to the workers in that both will be written off as part of expenditure for the period the costs were incurred.

Pallot [3] since the payments made for the acquisition of fixed assets by the government are written off in the year of acquisition irrespective of the useful life of the fixed assets, it follows that fixed assets like buildings and motor vehicles which will normally be seen on the balance sheet of a private sector business will be absent in the case of government. This explains why, for example, the Accountant-General's Statement No. 2 which is a statement of assets and liabilities of government does not indicate anything on the fixed assets of the government. Since fixed assets are not capitalized, it follows that there is no room for depreciation in government accounting system that uses cash basis of accounting. It should also be pointed out that since revenue is recognized only when cash is received, debtors as it is known in the private sector will be absent from government financial statements (but will, of course, be recorded).

In the private sector, accrued expenses are recognized as current liabilities and taken into consideration in determining the total debt of the organization. Government departments do not recognize current liabilities thereby giving a wrong impression of total government debt (if the liabilities are significant).

One other point to discuss on the topic is the role of fund accounting in government. In the case of a private sector business, the whole of the business is treated as an accounting entity. This implies that accounting measures and reporting are carried out in the name of one single entity. As a result, unless an asset is set aside for a specific purpose (such as replacement of a fixed asset) the organization's resources are available as a pool which can be used in any area of its operation to achieve the main goal of profit making. Thus, the pool of resources can be used to acquire fixed assets, pay wages or pay debt, Khumawala and Gordon [4].

However, in the case of the government that has diversity of goals and functions to carry out, the resources are not available as a pool to be spent on just any area of government operation at the discretion of the officials, Hopwood [5]. There are often restrictions on how available resources may be utilized on individual areas of government operation. The mechanism for carrying out the restriction is the fund accounting. Under this arrangement, separate funds are 
provided for carrying out different specific functions of government, Omolehinwa and Naiyeju [6]. A fund is the total amount of money set aside for a specific purpose. Each fund is then accounted for separately, so that the fund is the accounting entity on which accounting reports are based. Thus fund accounting can be defined as a method of accounting, which treats a fund as the accounting entity on which accounting reports are based rather than the organization as a whole, Anthony [7]. It should be remembered that the purpose of fund accounting is to ensure that the government organization uses the resources provided for each fund only for the purposes designated for the fund.

\subsection{Financial Reporting}

Financial reporting is a communication of financial statements and its related information from a venture to its stakeholders. The primary goal of financial reporting is to deliver high-quality information on reporting entities, to promote informed economic decisions making IASB [8]. This can confidently impact stakeholders when they are faced with making economic decisions (investments, credit decisions, and allocating resources) that may augment total capital markets efficiency [8] IASB, 2008; 2010).

The concept of financial reporting quality is wide and subsists of financial and nonfinancial information disclosure which is paramount for decision making. Financial reports should ascertain some qualitative criteria to prevent poor quality of information. IASB and FASB in their Conceptual framework posited that high quality is attained by obeying the objective and the qualitative characteristics of financial reporting information IASB [8]. Qualitative characteristics are "the traits that make the financial information valuable" IASB [8]. However, provision of relevant and quality information is restricted by one persistent factor: the costs of reporting information must be covered by its benefits IASB [8]. The qualitative characteristics studied are as follows; Relevance and faithful representation (fundamental characteristics); comparability, verifiability, timeliness and understandability (enhancing characteristics).

\subsection{Empirical Review}

Giroux [9] examines the impact of two proxies for audit quality on a model of public sector disclosure for a sample of municipal governments. He argue that more complete disclosures enhance the reputation of an independent auditing firm and that independent auditors, seeking to maintain a reputation of higher quality, positively influence the level of financial disclosures appearing in their clients' financial statements. Specifically, a variable indicating the presence of Big Eight auditor and audit fees were used as surrogates of audit quality. These were included in a model designed to explain variation in an index representing financial disclosures required under generally accepted accounting principles for Local Governments. The results provide evidence in support of the hypothesized relationship between audit quality and disclosure.
Giroux and McLelland [10] developed disclosure indexes of municipalities based on the anticipated needs of political groups. He develops a model that correlate between disclosure level with political and economic incentives of the groups actively involved in governmental processes of municipalities. The results suggest that each group of political power has only limited influence on disclosure quality.

Gore [11] conducted research in the USA focusing on governance structure and disclosure in Mayor Council (MC). The research used two variables in measuring disclosures: certificate of achievement and disclosure index. Disclosure index was measured by certificate of achievement plus unqualified opinion and quality of auditor (dummy variables big 6 audit firms) which they used control variables used by previous researchers; financial condition, size, wealth, regulation. The results found $\mathrm{CM}$ cities have higher disclosure compared to MC. Financial viability, population and wealth influenced the disclosure index.

Laswad, Fisher and Oyelere [12] examined the incentive of municipalities' manager to disclose financial report information to the bond market. He compared disclosure levels of municipal governments in Michigan, which requires GAAP, with those in Pennsylvania, which has unregulated disclosure. In the absence of disclosure regulation he finds that managers have bond market-induced incentives to disclose information. Controlling for other incentives to disclose, the evidence implies that regulation induces additional disclosures for low debt governments, and is not binding for high-debt governments.

Ingran [13] conducted research on 86 Local Governments in New Zealand. They investigated the determinants of internet financial reporting by Local Government. The research used the logit model. Some Local Governments in New Zealand disclose their financial statements in the website. They used dummy variables as dependent variable, 1 for Local Governments that disclose their financial statement in the website. Six variables used by Falkman and Tagesson [14] are examined: political competition, size, leverage, type of Local Authority, municipal wealth and Press visibility. Results indicate that leverage, municipal wealth, Press visibility, and type of council are associated with the Internet financial reporting.

Giroux and Jones [15] investigate municipal accounting in Sweden based on the new regulation in 1998. The research used the triangulation approach, survey, documentation study and interview. The research proposed some variables that influenced compliance, i.e., time (by using older accounting standard), ratio of income from municipal derived from government grants, size, dummy of political majority. The results suggested, large municipalities produce better accounting information and weak audit quality was an important factor that explains the lower compliance with accounting standards.

Udeh and Sopeken [16] investigated audit quality of Local Governments in England and Wales. The objectives of the research were to explore variables that influence audit quality. 
The research reveals that audit quality of Local Government is associated with number of government audit clients and Local Government type.

Ifeoluwapo [17] studied the Adoption of IPSAS and the Quality of Public Sector Financial Reporting in Nigeria using primary source of data and Chi-square test and Kruskal Wallis test were employed. Findings from the study showed that adoption of IPSAS would increase the level of reliance on the financial reporting of public sector organisations in Nigeria.

Obasi [18] examine the implication of International Public Sector Accounting Standard and Financial reporting quality in Lagos State, Nigeria employing primary source of data, with a given population of all the public sector workers in Lagos State. The sample size was 300 comprising public sector accountants and auditors using stratified random sampling technique. Data were collected with the aid of questionnaires. A total of 291 copies of questionnaire were retrieved from the respondents. Data were analyzed using paired sampled T-test. The study revealed that the adoption of IPSASs has a significant influence on financial report quality $(\mathrm{t}=-28.787, \mathrm{p}=0.000)$ and concluded that the adoption of IPSASs influenced financial report quality in Lagos State

\subsection{Theoretical Framework}

Theoretical framework is believed to be a way or mode of seeing, analyzing, interpreting, describing and predicting issues under investigation [19]. As such, institutional theory and theory of revenue exaction were adopted as the theoretical framework for the study.

\subsubsection{Institutional Theory}

The Institutional theory was propounded by Banker and Patton [20]. The theory asserted that the institutional environment can strongly influence the development of formal structures in an organization, often more profoundly than market pressures. Innovative structures that improve technical efficiency in early-adopting organizations are legitimized in the environment. Ultimately these innovations reach a level of legitimization where failure to adopt them is seen as "irrational and negligent" (or they become legal mandates). At this point new and existing organizations adopt the structural form even if the form does not improve efficiency. The theory further stipulates that the "institutional myths" are merely accepted ceremoniously in order for the organization to gain or maintain legitimacy in the institutional environment. Organizations adopt the "vocabularies of structure" prevalent in their environment such as specific job titles, procedures, and organizational roles.

The adoption and prominent display of these institutionally-acceptable "trappings of legitimacy" help to preserve an aura of organizational action based on "good faith". Legitimacy in the institutional environment helps to ensure organizational survival. The institutional theory is relevant to this study in that in the Local Government administration, statutory rules, societal norms and guidelines are put in place for workers to comply with. Employees are accountable for the work they are expected to do. Thus, accountability is the starting point for the analysis of management roles and management authority in Local Government administration.

\subsubsection{Agency Theory}

The relationships in business enterprises between managers, owners, and creditors are referred to as agency relationships. Similarly, the relationship between the political (public sector) manager and the voter can be described as an agency relationship whereby the voter is the principal and the political manager is the agent Zimmerman [21]. In this scenario, politicians are assumed to be self-interested, maximising agents, whereby the maximisation of their wealth depends on re-election, advancement, and current and future income, both pecuniary and non-pecuniary McKean [22]. Zimmerman notes that the interest of the agents and the principal can differ in several ways: the agents can shirk, consume perquisites, or engage in illegal acts. In addition, political managers, in the pursuit of achieving a higher office, can use the resources of the office to further their careers Baber [23]. For example the politician may sponsor strong environmental protection legislation to establish credibility as an environmentalist. They can also enter into informal contracts that trade current legislation for future support McKean [22]. Furthermore, they can devise ways to use the relatively low cost (sometimes free) media exposure to "create" and "solve" a "political crisis" in order to make them more popular McKean [22]. These activities give the voters (as the politicians principals) incentives to monitor the behaviour of the politicians.

Within this framework, voters are also being assumed to be self-interested and to act in such a way as to increase their wealth. Voters' wealth is related to the actions of their agents, directly through the politicians' power to levy taxes and their power to determine the mix and the quality of services provided to the voters (as citizens) and indirectly through the effect of property taxes on property value McKean [22]. Zimmerman states that though the contractual claims and benefits-sharing among the voters are not homogenous, each voter has an incentive to monitor the behaviour of the politicians; such as to reduce the outright theft and embezzlement and to monitor the level of perquisites consumed by the agent.

However, the voters are assumed to be rational and act only when the expected benefit exceed the expected cost of the action McKean [23]. Baber [23] notes that although the potential benefit of electing an agent that favours the interest of the voter can be significant, the probability that a single voter can influence the outcome of an election is very small. Therefore, the expected benefits of becoming informed of the politicians' intentions and how they will affect the voter are relatively insignificant, whereas the cost of obtaining such information would be substantial Dowis [24]. Hence, most voters lack pecuniary incentive to acquire information to improve their voting decision Dowis [24]. The voters tend to 
rely on intermediaries, called interest groups, who can affect the outcome of elections by distributing information that favours or disfavour candidates. Since interest groups have the power to influence the outcome of elections, they have an incentive to gather information about the behaviour and actions of the politicians Dowis [24]. If the politicians wish to be elected, they could not afford to dismiss the interests of these groups, and hence the politicians advocate policies that appeal to these groups.

Similar to other agency relationships, in this scenario, the interest group (the principal) and the politician (the agent in the public sector) share certain benefits and also certain costs. Therefore the elected politicians supply monitoring information to show that they are in fact honouring the preelection promises, and their incentives to do so increases as political competition increases Dowis [24]. The discussion above indicates that agency relationships in the public sector provide incentives to public sector managers to voluntarily disclose information that allows the monitoring of their actions.

Dowis [24] argues that the number and magnitude of wealth transfers administered by political agents may increase competition for public office. Increasing political competition makes it more costly for incumbent political agents to ignore pre-election agreements with supporting voters (or interest groups), so political agents have an incentive to bear greater monitoring costs by supplying more information which demonstrate their execution of preelection promises (Baber, 1983).

\section{Methodology}

The population of this study consists of Directors of Finance and accounts of all the twenty Baber (23) Local Government in Kaduna State of Nigeria. The study utilized census sampling techniques where all the population was adequately represented. Kothari [25] census sampling is a complete enumeration of all the elements in the population. This approach though may look a bit expensive, but it eliminates the biasness and sampling error that may likely occurred in selecting samples from the population Kothari [25]. In order to generate the necessary data for this study, a descriptive research design was adopted and information contained in the annual reports and accounts was elicited for the 23 Local Government for a period of 8 years (20092018) and inferential statistic was used to analyze using STATA 12 tool of analysis on the stated model:

$$
\mathrm{Y}=\mathrm{X}_{1}+\mathrm{X}_{2}+\mathrm{X}_{3}+\mathrm{X}_{4}+\mathrm{e}
$$

\section{Results and Discussion}

\subsection{Descriptive Statistics}

The sample descriptive is first presented in the table below where the mean, standard deviation, minimum, maximum, skewness, kurtosis and number of observations in the study are presented.

Table 1. Descriptive Statistics.

\begin{tabular}{llllllll}
\hline Variables & Mean & Std Dev. & Min & Max & Skewness & Kurtosis & Obs \\
\hline DAC & 12.33933 & 3.332056 & 5.327876 & 18.00144 & -0.0574627 & 1.704861 & 230 \\
RCEX & 14.23333 & 2.727973 & 8 & 20 & 0.0162238 & 2.261958 & 230 \\
RECX & 2.906667 & 1.322732 & 1 & 9 & 1.324259 & 6.273317 & 230 \\
RCRV & 4.753333 & 0.7852385 & 3 & 6 & 0.045027 & 2.311994 & 230 \\
FSIZ & 16.84124 & 3.15683 & 11.1805 & 21.6037 & -0.057715 & 1.38119 & 230 \\
\hline
\end{tabular}

Source: STATA OUTPUT

The result from table 1 above shows that the mean value of financial reporting quality proxy by Discretionary accrual is 12.34 with a standard deviation of 3.33 . This result implies that there is wide variation of financial reporting quality across the Local Government in Kaduna State, Nigeria, which is further attested to the minimum of 5.32 and maximum of 18 . The variability serves as a useful indicator for further analysis of the data.

About the independent variables, RCEX has a mean value of 14.23 with standard deviation of 2.73. This implies that RCEX deviate significantly across the study Local Government in Kaduna state, Nigeria. The minimum value of 8 and maximum of 20 also shows significant variability in the data. In addition, RCEX has an average mean value of 2.91 and standard deviation of 1.32. RCRV reveals an average of 4.75 and standard deviation of 0.79 with their respective minimum and maximum value of 1 and 9 , and 3 and 6 respectively showing the disparity in their behaviour of the variables across the sample Local Government in Kaduna
State, Nigeria.

SIZE which was represented by the population size of each Local Government in the State has a mean value of 16.84 with standard deviation of 3.16. The higher value of the average mean suggests that the Local Government in Kduna State, Nigeria is of various sizes. The minimum value of 11 and maximum value of 22 further substantiate the result.

In general, all the standard deviations of all the variables of the Local Governments in Kaduna State, Nigeria vary significantly from their respective means of the data indicating that there are wide variations regarding the study Local Government in Kaduna State, Nigeria in terms of board characteristics, audit committee and firm specific characteristics. In addition, the Skewness and Kutosis statistics reveals that the data obtained for all the variables both dependent and independent variables are normal. This substantiates the validity of the regression results. 


\subsection{Presentation and Interpretation of Regression Result}

This section presents and analyzed the OLS result of the study. The summary of the OLS result is presented in table below.

Table 2. Regression Result.

\begin{tabular}{llll}
\hline Variable & Coefficient & t-value & P-Value \\
\hline Constant & 0.0428727 & -0.02 & 0.986 \\
RCEX & -0.1401264 & -2.36 & 0.020 \\
RCAX & 0.4391945 & 2.37 & 0.019 \\
RCRV & -0.4543829 & -2.70 & 0.008 \\
FSIZ & 0.807725 & 15.28 & 0.000 \\
R $^{2}$ & & & 0.7660 \\
Adjr $^{2}$ & & & 0.7456 \\
F- stat & & & 37.38 \\
P-value & & & 0.000 \\
\hline
\end{tabular}

Source: Stata Output

The cumulative correlation $\left(\mathrm{r}^{2}\right)$ between dependent variable and all the independent variables is 0.7660 indicating that the relationship between financial reporting quality measured by earnings management and Local Government accounting bases in Nigeria using Kaduna as study area is $76.6 \%$ which is strongly and statistically significant. This implies that for any changes in the accounting bases, financial reporting quality will be directly or inversely affected.

The cumulative adjusted $r^{2}(0.7456)$ which is the multiple coefficient of determination gives the proportion of percentage of the total variation in the dependent variable explained by the explanatory variables jointly. Therefore, it signifies $74.56 \%$ of total variation in Local government accounting bases on financial reporting quality in Nigeria while, the remaining $25.45 \%$ are accounted for by the other factors that were not captured in this study. The f-statistic value of 37.38 which is significant at $1 \%$ suggests that the model is fitted and therefore provides variables that determine financial reporting quality Local Government in Nigeria.

\section{Findings}

The study reveals that the cumulative effect of explanatory variables are statistical significant at 5\% significant level to account for the effect of Local Government accounting bases on the financial reporting in Nigeria using Kaduna state as a case. Also, it was found that the individual explanatory variable could not produce any significant effect on the Local Government accounting bases on financial reporting in Nigeria.

\section{Conclusion and Recommendations}

This study was conducted with a view to analyze the effect of Local Government accounting on financial reporting in Nigeria with particular reference to Kaduna State. The result suggests that the effect of combine explanatory variables on the financial reporting is significant and sufficient to justify the financial reporting system in the Local Government in Kaduna State. However, the study could not establish any significant effect of the individual explanatory variable on the financial reporting in the Local Governments in Kaduna State. In order to ensure reliable financial reporting, there is the need to ensure consistence in the accounting basis that the Local Governments may adopt. This will guarantee uniformity in the informational content of the report that will be reliable and verifiable.

\section{References}

[1] Akinyele, T. A. (1981). Budgetary System in Presidential Government: Factors for Effective Reform. Public Service Lecture at Nigeria Institute of International Affairs, Lagos, 4th November.

[2] McCosh, A. M., Whiting, E. and Howell, S. (1981). Planning and control systems and their evolution during inflation. Manchester Business School and Centre for Business Research.

[3] Pallot, J. (2008). Accounting and Financial Management Reforms in the New Zealand Central Government: Context and Critique. Paper for the MENSAGEM DA GOVERNADORA À ASSEMBLEIA LEGISLATIVA.

[4] Khumawala, S. B. and Gordon, T. P. (1997). Bridging the credibility of GAAP: Individual donors and the new accounting standards for nonprofit organizations. Accounting Horizons, 11(3), 45.

[5] Hopwood, A. G. (1988) Information Systems and Organizational Reality, Occasional Paper No. 5, Thames Valley Regional Management Centre, forthcoming

[6] Omolehinwa, E. O. and Naiyeju, J. K. (2011). Theory and practice of government accounting in Nigeria: Pumark Niheria Limited.

[7] Anthony, K. T. (1978). Mistake, disclosure, information, and the law of contracts. The Journal of Legal Studies, 7(1), 1-34.

[8] International Accounting Standards Board, 2008. Exposure Draft of An Improved Conceptual Framework for Financial Reporting. ISBN: 978-1-905590-65-0

[9] Giroux, H. (2002). Neoliberalism, corporate culture, and the promise of higher education: The university as a democratic public sphere. Harvard educational review, 72 (4), 425-464.

[10] Giroux, G. and McLelland, A. J. (2003). Governance structures and accounting at large municipalities. Journal of Accounting and Public Policy, 2 2(3), 203-230.

[11] Gore, C. J. (2004). Commentary on how to interpret changes in an athletic performance test. Sportscience, 8 .

[12] Laswad, F., Fisher, R. and Oyelere, P. (2005). Determinants of voluntary Internet financial reporting by local government authorities. Journal of Accounting and Public Policy, 24 (2), 101-121.

[13] Ingram, R. E. (1984). Toward an information-processing analysis of depression. Cognitive therapy and research, 8 (5), 443-477. 
[14] Falkman, P., and Tagesson, T. (2008). Accrual accounting does not necessarily mean accrual accounting: Factors that counteract compliance with accounting standards in Swedish municipal accounting. Scandinavian Journal of Management, 24 (3), 271-283.

[15] Giroux, G., and Jones, R. (2011). Measuring audit quality of local governments in England and Wales. Research in Accounting Regulation, 23 (1), 60-66.

[16] Udeh, F., and Sopekan, S. (2015). Adoption of IPSAS and the quality of public sector financial reporting in Nigeria. Research Journal of Finance and Accounting, 6 (20), 1-9.

[17] Ifeoluwapo A. O. (2018) Implication of International Public Sector Accounting Standard and Financial reporting quality in Lagos State, Int. J. Adv. Res. 7 (1), 1124-1129.

[18] Obasi, A. H. (2008). Creating positive change in community organizations: A case for rediscovering Lewin. Nonprofit Management and Leadership, 18 (4), 485-496.

[19] Meyer, H. D., and Rowan, H. D. M. B. (2012). New Institutionalism in Education, The. SUNY Press.
[20] Banker, R. D., and Patton, J. M. (1987). Analytical agency theory and municipal accounting: An introduction and an application. Research in governmental and nonprofit accounting, 3(Part B), 29-50.

[21] Zimmerman, J. L. (1977). The municipal accounting maze: An analysis of political incentives. Journal of Accounting Research, 107-144.

[22] McKean, R. N. (1964). Divergences between individual and total costs within government. The American Economic Review, 54 (3), 243-249.

[23] Baber, W. R. (1983). Toward understanding the role of auditing in the public sector. Journal of Accounting and Economics, 5, 213-227.

[24] Downs, A. (1957). An economic theory of political action in a democracy. Journal of political economy, 65 (2), 135-150.

[25] Kothari, C. R. (2004). Research methodology: Methods and techniques. New Age International. 